\title{
'What a kitty!': Women's physical appearance and animal metaphors in Montenegro
}

Violeta Vujković, University of Montenegro

Milica Vuković-Stamatović, University of Montenegro

\section{Abstract}

Animals present a common source of metaphors conceptualising humanity and, consequently, women. The aim of this paper is to explore how women's physical appearance is conceptualised through animal metaphors in Montenegrin webpages (the .me domain). We find that women's looks are most often likened to those of a cat (kitten, kitty), fish, mare, snake, tigress, and duck. The choice of an animal that a woman is compared to and the associated characteristics reflect entrenched cultural views which prioritise women's physical appearance. By comparing our results to those from the scholarly literature, we also conclude that the choice of some metaphors may be culturally specific to Montenegro and/or perhaps the wider Western Balkan region.

\section{Keywords}

Conceptual metaphor, animal metaphors, discourse, gender and language, Montenegro 


\section{Introduction}

Animal metaphors are ubiquitous and men and women alike are frequently referred to as some sort of an animal across languages. The words kitty, doe, or mare are used in common descriptions of women in many languages. However, the quality that a particular animal is associated with varies across languages and cultures, at least to some extent. Thus, some animals may invoke attractiveness and grace, for instance, while others may connote the opposite qualities, such as physical unattractiveness, clumsiness, etc. What animals are used and what qualities they convey depends on the language and culture in which such metaphors are used. This paper will shed a light on how women's physical appearance is conceptualised via animal metaphors in the case of Montenegro. We will investigate which animals women are compared to with regards to their physical appearance and what influences such choices, in a collection of examples extracted from Montenegrin webpages. Finally, we will address what these choices convey and whether they encode some underlying positive or negative values in the Montenegrin context.

Depending on which linguists are consulted, one may say that Serbia, Croatia, Montenegro, and Bosnia and Herzegovina share the same, common language ${ }^{1}$, or that they, at the very least, have languages that are highly mutually intelligible. ${ }^{2}$ Yet, despite the linguistic commonalities, the historical legacies, religions, and many cultural elements of the four countries vary. In this light, while in many aspects it makes sense to study language and culture in the region as a whole, studies devoted to specific subregions, i.e. countries, as we have done in this paper, offer potential insights that could be missed by a broader analysis. In this particular case, amongst the aforementioned four countries, Montenegro has the strongest historical roots in patriarchy, which bears an impact on how a woman is perceived in its society ${ }^{3,4}$ - this was the main reason why we decided to focus solely on Montenegrin data in this study. Additionally, we were also motivated by the fact that, across the region, least attention has thus far been

\footnotetext{
${ }^{1}$ In the past referred to as Serbo-Croat, presently sometimes referred to as BCMS - Bosnian-Croatian-MontenegrinSerbian. For more on this debate, see, inter alia, the following: Rajka Glušica, 'Crnogorski jezik u čeljustima nacionalizma.' Riječ, 4 (2010), 25-45; Hasnija Muratagić-Tuna, Bosanski, hrvatski, srpski aktuelni pravopisl: sličnosti i razlike (Sarajevo: Bosansko filološko društvo, 2005); Lada Badurina, Ivo Pranjković and Josip Silić (eds.), Jezični varijeteti i nacionalni identiteti (Zagreb: Disput, 2009); Snježana Kordić, 'Policentrični standardni jezik' in Jezični varijeteti i nacionalni identiteti, ed. by Lada Badurina, Ivo Pranjković and Josip Silić (Zagreb: Disput, 2009): pp. 83108; Jagoda Granić, 'Planiranje statusa i planiranje korpusa bosanskog/bošnjačkog, hrvatskog i srpskog standarda', in Die Unterschiede zwischen dem Bosnischen/Bosniakischen, Kroatischen und Serbischen, ed. by Branko Tošović and Arno Wonisch (Graz-Zagreb: Institut für Slawistik der Karl-Franzens-Universität Graz, 2008), pp. 17-33; and Ranko Bugarski. Jezik i identitet (Beograd: Biblioteka XX vek, 2010).

${ }^{2}$ In Montenegro, Montenegrin has been the official language since the country declared its independence in 2006. However, Serbian, Crotian and Bosnian are also in official use, according to Montenegro's Constitution. They are taught as one subject in primary and secondary schools, called "Montenegrin-Serbian/Croatian/Bosnian". At the university level, however, the linguistic situation is more complex - Montenegrin and Serbian are taught in separate departments.

${ }^{3}$ Ivan Tepavčević, 'Jedan pogled na položaj žena u Crnoj Gori u XIX i početkom XX vijeka.' Folia Linguistica et Litteraria, 21 (2018), 237-247.

${ }^{4}$ Slavica Perović and Milica Vuković-Stamatović, 'Universality and cultural variation in the conceptualisation of love via metaphors, metonymies and cultural scripts: the case of Montenegrin.' Círculo de Lingüistica Aplicada a la Comunicación, 85 (2021), 45-61.
}

Vujković and Vuković-Stamatović, SLOVO, 34, 1, 2021. DOI: 10.14324/111.444.09546839.1239. 
dedicated to the issue of language and gender in Montenegro, as well as by the fact that narrowing our focus meant collecting and processing a significantly smaller dataset, which allowed for a more in-depth study than would be possible with a corpus comprising the webpages from the entire region.

The first part of this paper provides the theoretical background on which the present paper relies. After briefly presenting the broad findings in the area of language and gender, Conceptual Metaphor Theory and the discourse approach to metaphor, we will review the studies of the metaphor woman as an animal undertaken in various languages to date, after which we introduce the corpus and the research method. The second part of the paper is devoted to the analysis and the interpretation of the results.

\section{Theoretical background}

This study can broadly be subsumed under the general field of gender and language studies, as well as, more concretely, within cognitive linguistic studies and the discourse approach to metaphor. Thus, the two subsections of this theoretical review are dedicated to these two broad fields - gender and language, and metaphor.

\subsection{Gender and language}

Gender and language studies were launched in the 1970s after the publication of the seminal essay Language and Woman's Place by Robin Lakoff. Ever since, studies exploring gender asymmetries and inequalities, as encoded in language, typically employing interdisciplinary methods, have been on the rise. They seek to investigate how gender differences are entrenched in and propagated through language in various cultures and societies.

Language not only reflects reality but also constitutes it - bearing this basic premise in mind, gender and language researchers explore how social discrimination against certain genders is seen in and propagated through language. This is a broad research field which explores the ways in which gender and gender roles are linguistically constructed. Much of this research finds that traditional prejudices against and stereotypes about women are also deeply entrenched in language.

Lakoff divides the field of gender and language studies into two strands of research: on the one hand, one can explore how women talk, and, on the other hand, how women are talked about. ${ }^{5}$ Our present study is situated in the latter strand of such research. In exploring how women are talked about, authors may look into the overt or covert sexism in language. ${ }^{6}$ The former refers to the unambiguous language referring to a woman in a negative way, whereas the latter, which is typically more common, is accomplished subtly and indirectly, and understood only

${ }^{5}$ Robin Lakoff, 'Language and woman's place.' Language in Society, 2.1 (1973), 45-79.

${ }^{6}$ Sarah Mills, Language and Sexism (Cambridge: Cambridge University Press, 2008).

Vujković and Vuković-Stamatović, SLOVO, 34, 1, 2021. DOI: 10.14324/111.444.0954-

6839.1239. 
in a given context. The present study will explore both these aspects, as they have both arisen in the data.

Different analytical frameworks may be applied in gender and language studies. The most common methodologies include the semantic analysis of how vocabulary differs by sex and of how we talk about gender, the pragmatic analysis of various linguistic strategies employed by different sexes, and the critical discourse analysis of how sex and gender roles are depicted and constructed in various public discourses. Part of this research specifically focuses on how women are metaphorically conceptualised, i.e. what metaphors are used to talk about them. This type of investigation typically combines semantic analysis with critical discourse analysis. Thus, it has been found that a woman can be conceptualised in many ways, e.g. as food (cookie, cupcake, tart, honey ${ }^{7}$ ), animals (bunny, chick ${ }^{8}$ ), plants (violet, rose ${ }^{9}$ ), means of transport $\left(\mathrm{car}^{10}\right)$, etc. In this paper, our attention will be specifically devoted to how women's looks are metaphorically compared to animals in a corpus of Montenegrin webpages.

\subsection{Conceptual metaphor}

Theoretically and methodologically, this paper is based on the Conceptual Metaphor Theory, as established by Lakoff and Johnson. ${ }^{11}$ The authors state that metaphor is profoundly engrained in how we conceptualise the world and that conceptual metaphors are realised in language through different linguistic expressions. The conceptual metaphor functions as a mental mechanism that helps us understand and organise reality. Concepts which we find complex, foreign and abstract can be rearranged and reduced to familiar experiences by using conceptual metaphors. ${ }^{12}$ These familiar experiences may involve animals and many of the more abstract concepts and phenomena are frequently compared to animals and animalistic behaviour through metaphors.

In this subsection, we will briefly explore how metaphor is viewed in cognitive studies and present the discourse approaches to metaphor, before we present the animal metaphors used to talk about women in more detail.

\subsubsection{Metaphor in cognitive linguistics}

\footnotetext{
${ }^{7}$ Caitlin Hines, 'Rebaking the pie: the woman as dessert metaphor,' in Reinventing Identities: The Gendered Self in Discourse, ed. by Mart Bucholtz, Anita C. Liang, and Laurel A. Sutton (Oxford: Oxford University Press, 1999), pp. 145162.

${ }^{8}$ Caitlin Hines, 'Foxy chicks and playboy bunnies: A case study in metaphorical lexicalisation.' Amsterdam Studies in the Theory and History of Linguistic Science Series, 4 (1999), 9-24.

${ }^{9}$ Slavica Perović, Pojmovna metafora kulturno srodnih pojmova (Podgorica: CANU, 2017).

${ }^{10}$ Vesna Bratić and Milica Vuković-Stamatović, 'Commodification of women through conceptual metaphors: The metaphor woman as a car in the Western Balkans.' Gender and Language, 10.3 (2017), 51-76.

${ }^{11}$ George Lakoff and Mark Johnson. Metaphors We Live by (Chicago and London: The University of Chicago Press, 1980).

12 Lakoff and Johnson, p. 43.
} 
Cognitive linguistics has initiated a new way of studying language. Linguists advocating this strand of research argue that people form their basic conceptual structures through physical, sensory, intellectual or emotional experiences arising from their interaction with the environment. In cognitive linguistics, conceptual metaphor has been one of the more frequent topics of research. As stated above, conceptual metaphor was first studied by Lakoff and Johnson, who reject the traditional definitions of metaphor as a figure of speech and a rhetorical device, and argue that metaphor permeates our entire cognition. They argue that the concepts that govern our thoughts, also govern our lives (the way we function, the way we communicate with people, etc.).

Conceptual metaphor is based on understanding complex and unfamiliar concepts through simpler ones, i.e. through the mapping of the source domain onto the target domain. The source domain is the conceptual domain from which metaphorical expressions are drawn, and the target domain is the one that is talked of metaphorically. Source domains are the entities and phenomena that we understand more easily and they are typically concrete: animals, food, plants, parts of the human body, etc. On the other hand, target domains usually include: time, politics, religion, human relationships, life, moral categories and similar abstract concepts. ${ }^{13,14}$

Lakoff and Johnson state that our conceptual system is fundamentally metaphorical. ${ }^{15}$ In order to illustrate this, they use the conceptual metaphor argument is war, among others. The abstract concept (argument) is understood by means of a phenomenon that is more familiar and more concrete (war). This conceptualisation is reflected in a number of linguistic realisations such as: unbeatable claims, attack positions, indefensible arguments, etc.

\subsection{2. (Critical) discourse approaches to metaphor}

Conceptual knowledge is not only grounded in the physical world - often, it is based on the social world and thus the choice of metaphor can reflect an ideology. ${ }^{16}$ While Lakoff and Johnson ${ }^{17}$ argue for a subconscious and automatic choice of metaphor, Charteris-Black ${ }^{18}$, among others, argues for a conscious choice of metaphors in some cases, in order to accomplish a particular communicative purpose.

Such views have given rise to an array of discourse approaches to metaphor, most of which are critical. In these approaches, metaphor is studied in context, as "context-boundedness, strategical fuzziness, ideological bias" need to be accounted for, bearing in mind that cognitive and social study of metaphor should go hand in hand. ${ }^{19}$ Examples of such analyses may be

\footnotetext{
${ }^{13}$ Zoltan Kövecses, Metaphor: A Practical Introduction (Oxford: Oxford University Press, 2010).

${ }^{14}$ Duška Klikovac, Metafore u mišljenju i jeziku (Beograd: Biblioteka XX vek, 2004).

${ }^{15}$ Lakoff and Johnson, p. 4.

${ }^{16}$ Jonathan Charteris-Black, Corpus Approaches to Critical Metaphor Analysis (New York: Palgrave Macmillan, 2004).

${ }^{17}$ Lakoff and Johnson, p. 4.

${ }^{18}$ Charteris-Black, p. 10.

19 Jörg Zinken, lina Hellsten and Brigitte Nerlich, 'Discourse metaphors.' Body, Language and Mind, 2 (2008), 363385 (364).
}

Vujković and Vuković-Stamatović, SLOVO, 34, 1, 2021. DOI: 10.14324/111.444.09546839.1239. 
Musolff's work on the representation of immigrants ${ }^{20}$ and the representation of the European Union ${ }^{21,22}$, Semino's research on the metaphorical framing of illness ${ }^{23}$, and Semino and Masci's study on the use sport metaphors in politics. ${ }^{24}$ In addition, most of the studies on how women are conceptualised in various languages and societies have also been based on a (critical) discourse analysis of conceptual metaphors. A brief review of the animal metaphors portraying women is given in the following section.

\subsubsection{Conceptual metaphor: woman is an animal across languages and cultures}

According to Kövecses, animal metaphors can be put as follows: people are animals and human behaviour is animal behaviour. ${ }^{25}$ He points out that animal metaphors are used in various languages to illustrate human behaviour and that sometimes even domains that appear to be clear and straightforward can be conceptualised by other domains.

Studying how women are metaphorically conceptualised may help to understand how speakers of different languages and in various cultural contexts perceive them. In this vein, López Rodríguez discussed the use of animal metaphors in English and Spanish. ${ }^{26}$ Finding similarities between the two languages, she noticed that women are usually portrayed as small and helpless animals, whose main purpose is to provide entertainment and food. According to her research, animal metaphors are almost always used to describe women's negative characteristics. As an example, she cites the metaphor woman is a cat and points out that in English this metaphor is used to depict a malicious woman or a prostitute.

Tipler and Ruscher conduct their study in the U.S. context and find that animal metaphors for women reflect cultural views that focus on a "sex-based power differential", i.e. women are either perceived as hunters, in which case they are seen as inappropriately dominating, or they are perceived as the hunted, in which case they are appropriately subordinate. ${ }^{27}$ Authors also find that animalistic metaphors perpetuate the prejudice about the roles of women considered appropriate by society.

\footnotetext{
20 Andreas Musolff, 'Dehumanising metaphors in UK immigrant debates in press and online media.' Journal of Language Aggression and Conflict, 3, 1 (2015), 41-56.

${ }^{21}$ Andreas Musolff, Metaphor and Political Discourse: Analogical Reasoning in Debates about Europe (Basingstoke: Palgrave Macmillan, 2004).

22 Andreas Musolff, Political Metaphor Analysis: Discourse and Scenarios (London: Bloomsbury Publishing, 2016).

${ }^{23}$ Elena Semino, Metaphor in Discourse (Cambridge: Cambridge University Press, 2008).

${ }^{24}$ Elena Semino and Michela Masci, 'Politics is football: metaphor in the discourse of Silvio Berlusconi in Italy.' Discourse \& Society, 7.2 (1996), 243-269.

25 Kövecses, p. 153.

${ }^{26}$ Irene López Rodriguez, 'Of women, bitches, chickens and vixens: animal metaphors for women in English and Spanish.' Cultura, Lenguaje y Representación/Culture, Language and Representation, 7.7 (2009), 77-100.

${ }^{27}$ Caroline Tipler and Janet Ruscher, 'Dehumanizing representations of women: The shaping of hostile sexist attitudes through animalistic metaphors.' Journal of Gender Studies, 28.1 (2019), 109-118 (111).
}

Vujković and Vuković-Stamatović, SLOVO, 34, 1, 2021. DOI: 10.14324/111.444.09546839.1239. 
Barasa and Opande study the animal metaphors for women in Bukusu and Gusii societies in Kenya. ${ }^{28}$ They find that women are likened to pets, livestock and wild animals, and that they are commonly conceptualised as subjugated to men and inferior. The authors conclude that animal metaphors for women "reinforce the gender ideologies as a belief system", which portrays women as "inferior, worthless and weak". ${ }^{29}$ Women are thus marginalised, on the one hand, and, on the other, they are frequently perceived as sexual objects valued for their beauty. Silaški conducted a study dealing with the realisations of the conceptual metaphor woman is an animal in Serbian. ${ }^{30}$ The most commonly used animals in the realisations were mačka (cat), guska (goose), patka (duck), lavica (lioness), etc. She found that most of the animal metaphors for women had negative connotations and that they were used for the purpose of semantic derogation, concluding that Serbian has a tendency towards downgrading a specific social group, i.e. women, who are considered marginal or inferior.

Kilyeni and Silaški conducted a contrastive cognitive-linguistic analysis of the metaphor woman is an animal in Serbian and Romanian. ${ }^{31}$ The authors noticed that similar expressions were used in both languages to express positive or negative characteristics related to women. They found that "the animal metaphors analysed are generally used disparagingly, with negative behavioural and/or sexual connotations, and hence reveal the sexism entrenched in the two languages". ${ }^{32}$

Halupka-Rešetar and Radić also noticed that in Serbian animal names are often used as a means of insult in the conceptualisation of women. ${ }^{33}$ In order to support their argument, they explored the following metaphors: woman is a ewe, woman is a cow, woman is a sow, etc.

Very few studies concerning this topic have been conducted in Montenegro. To our best knowledge, only three studies have dealt with the metaphors used to portray women. One of them was carried out by Bratić and Vuković-Stamatović, who explored the metaphor woman as a car as a metaphor commodifying women in Bosnian-Croatian-Montenegrin-Serbian. ${ }^{34}$ Perović investigated how women are represented in Montenegro via various metaphors. ${ }^{35}$ Inter alia, Perović dealt with two basic animal metaphors conceptualising women: woman is a small animal (e.g. pile (chick) and mače (kitten)) and woman is a big animal (e.g. krava (cow) and lavica (lioness)). She found that the latter was unusually frequent in the Montenegrin corpus she analysed, concluding that that could be a cultural specificity of Montenegro. In a pilot

\footnotetext{
${ }^{28}$ Margaret Nasambu Barasa and Isaac Nilson Opande. 'The use of animal metaphors in the representation of women in Bukusu and Gusii proverbs in Kenya.' Africology: The Journal of Pan African Studies, 10.2 (2017), 82-108. ${ }^{29}$ Barasa and Opande, p. 104.

30 Nadežda Silaški, 'Animal metaphors and semantic derogation-do women think differently from men?' Gender Studies, 12 (2013), 319-332.

${ }^{31}$ Annamaria Kilyeni and Nadežda Silaški, 'Beauty and the beast from a cognitive linguistic perspective: Animal metaphors for women in Serbian and Romanian.' Gender Studies, 13.1 (2014), 163-178.

32 Kilyeni and Silaški, p. 176.

33 Sabina Halupka-Rešetar and Biljana Radić. 'Animal Names Used in Addressing People in Serbian.' Journal of Pragmatics, 3 (2003), 1891-1902.

${ }^{34}$ Bratić and Vuković-Stamatović, pp. 51-76.

35 Perović, p. 59.
} 
study, Vujković explored three animal metaphors depicting women in a Montenegrin corpus (woman as a cat/fish/lioness); this present study builds on that piece of research. ${ }^{36,37}$

The findings from various languages here mentioned reveal a common thread - they point to a frequent use of the animal metaphors for women and to the negative underlying ideology motivating their choice, which is perpetuated by their use.

\section{Data and methodology}

This dataset was collected from Montenegrin webpages (the .me domain), which are written in Bosnian-Croatian-Montenegrin-Serbian.

Due to the fact that metaphorical expressions always contain lexical units from their source domain, it was reasonable to begin the study by selecting a potential source domain. ${ }^{38}$ In summer 2019, a Google search was conducted from Montenegro using, as the search criteria, the lexical items from the source domain, often in conjunction with the lexical items from the target domain. For instance, when searching for the linguistic instantiations of the conceptual metaphor woman is a cat, the examples of the search strings included the following: "prava mačka" / "baš mačka" (a real cat/kitty/pussy (cat)), "mačkica" (kitty), "vidi mačku" ("see a cat/pussy (cat)/kitty"), as well as the combinations with the target vocabulary, e.g. "ona je * mačka" (she is * cat/kitty/pussy (cat)), "žena * mačka" (woman * cat/kitty/pussy (cat)). Various online word lists containing the names of animals were consulted and search strings similar to the ones above were applied for all common animals. An additional criterion was that the expression found clearly referred to a woman's physical appearance. Such a procedure yielded 106 excerpts from the internet corpus, which served as our dataset. Most of the excerpts come from newspaper and magazine articles, reader comments sections and chat fora.

Having collected the dataset, the authors checked the metaphoricity of the animalistic expressions using the procedure for identifying metaphorical language in the real discourse the Metaphor Identification Procedure (MIP). ${ }^{39}$ This procedure is used to determine whether the usage of the lexical units in a particular context can be described as metaphorical or not..$^{40}$ The method involved reading the excerpts to get a general understanding of the meaning. Then, the lexical units were determined and their contextual meaning was established. After that, for each lexical unit, it was determined whether their basic meaning (as in a dictionary) and their contextual meaning were in contrast. If they were, the expressions were confirmed as metaphorical.

\footnotetext{
${ }^{36}$ Violeta Vujković, 'The conceptual metaphor woman is an animalin Montenegrin webpages.' Logos et Littera, 6.1 (2019), 67-80.

${ }^{37}$ Violeta Vujković, Konceptualizacija žene putem animalnih metafora u korpusu britanskih i crnogorskih internet stranica (unpublished master's thesis, University of Montenegro, 2020).

${ }^{38}$ Anatol Stefanowitsch, and Stefan Gries, Corpus-Based Approaches to Metaphor and Metonymy (Berlin: Mouton de Gruyter, 2006).

39 Pragglejaz Group, 'MIP: A Method for Identifying Metaphorically Used Words in Discourse.' Metaphor and Symbol, 22.1 (2007), 1-39.

${ }^{40}$ Gerard Steen, 'Towards a procedure for metaphor identification.' Language and Literature, 11.1 (2002), 17-33.
} 
The excerpts were then grouped according to the type of an animal they referred to, after which the authors proceeded to the analysis, employing a discourse approach, which was briefly introduced earlier.

\section{Analysis}

While collecting the data for our corpus, we found various realisations of the conceptual metaphor, woman is an animal. Some of them were used to convey the positive characteristics of a woman's physical appearance and some to express the negative ones. An overview of these animal metaphors is given in Table 1 below. The metaphors are ordered by the frequency of their instantiations. The polarity attractiveness/unattractiveness is indicated, as well as the additional qualities which the expressions were found to convey in the dataset.

As can be seen, we found thirteen animal metaphors conceptualising female physical looks on the Montenegrin webpages. All of them expressed qualities which are either attractive or unattractive, and none of them conveyed physical properties that could not be related to how appealing or not a woman looks. The distribution of the metaphors conceptualising good physical appearance vs. those conceptualising bad looks appears to be more or less balanced (seven of them conveyed attractiveness, whereas six conveyed unattractiveness). Our analysis will be divided into two parts based on these two types of physical qualities conveyed by the metaphors. 
Table 1. An overview of the animal metaphors conceptualising women's physical appearance

\begin{tabular}{|c|c|c|c|}
\hline $\begin{array}{l}\text { Metaphor: } \\
\text { woman is a... }\end{array}$ & $\begin{array}{ll}\text { Attractive } \quad(+) & \text { or } \\
\text { unattractive } & (-) \\
\text { physical appearance }\end{array}$ & Additional qualities & $\begin{array}{l}\text { No. of } \\
\text { instantiations }\end{array}$ \\
\hline cat & + & $\begin{array}{l}\text { sexuality, independence, wild } \\
\text { nature }\end{array}$ & 21 \\
\hline fish & + & a great body, sexuality & 18 \\
\hline mare & - & $\begin{array}{l}\text { obesity, awkward height } \\
\text { woman, sometimes vulgarity }\end{array}$ & 16 \\
\hline snake & + & $\begin{array}{l}\text { an exceptionally well-sculpted } \\
\text { body }\end{array}$ & 12 \\
\hline sow & - & $\begin{array}{l}\text { obesity, bulkiness, smelliness, } \\
\text { dirt }\end{array}$ & 9 \\
\hline duck & - & $\begin{array}{l}\text { pouting and big lips; an } \\
\text { awkward bodily constitution, } \\
\text { awkward walk resulting from } \\
\text { such a constitution }\end{array}$ & 9 \\
\hline tigress & + & exceptional sexual energy & 6 \\
\hline giraffe & - & $\begin{array}{l}\text { awkward height, awkward walk } \\
\text { resulting from extreme height }\end{array}$ & 4 \\
\hline doe & + & $\begin{array}{ll}\text { beauty, } & \text { tenderness, } \\
\text { graciousness } & \\
\end{array}$ & 3 \\
\hline she-elephant & - & $\begin{array}{l}\text { obesity, large and awkward } \\
\text { constitution }\end{array}$ & 3 \\
\hline bear & - & $\begin{array}{l}\text { obesity, large constitution, } \\
\text { lacking femininity, hairiness }\end{array}$ & 2 \\
\hline gazelle & + & slim body, elegant walk & 2 \\
\hline chicken & + & $\begin{array}{l}\text { (used metonymically) } \\
\text { chicken legs standing for } \\
\text { attractive women's legs }\end{array}$ & 1 \\
\hline
\end{tabular}

\subsection{Animal metaphors conceptualising attractive physical appearance}

In this category of metaphors the source domains included the following animals: cat, fish, tigress, doe, gazelle, chicken and snake. Amongst these, cat and chicken belong to domesticated animals; however, cats are known for their independence and, in a way, stand out amongst the domesticated animals, whereas the chicken metaphor was instantiated just once in the corpus. In addition, all of them are of a relatively small size. It appears that attractive physical looks are typically associated with small-sized wild animals. 
The most commonly used animal metaphor in the Montenegrin webpages was the metaphor woman is a cat. While searching through various webpages, we came across 21 realisations of this metaphor. Here we will present some of them:

1) AUU, KAKVA MAČKA! Zilha ZAPALILA Instagram OVOM fotkom - Zauzela pozu i pokazala TOP FIGURU (tracker_sd.contentexchange.me)

[OUCH, WHAT A KITTY! Zilka BURNED Instagram with THIS photo - She posed and showed her GREAT FIGURE]

2) KAKVA MAČKA: Cecina kćerka izdominirala u mini haljini, internet proključao! (https://montenegroclick.me/)

[WHAT A CAT: Ceca's daughter dominated in her mini-dress, the internet is boiling!]

3) Prava mačkica! Hrvatica u kožnom kombinezonu iz kog viri brus - jedva joj je obuzdao grudi. (tracker_adria.contentexchange.me)

[True kitty! The Croatian in a leather jumpsuit with her bra sticking out - it was hardly able to contain her breast.]

All the three examples above were posted as headlines and invite the reader to take a look at the photos of young, attractive women, dressed scantily, with the emphasis on their sexuality. Also, without even reading these headlines, one may notice an over-presence of capitalised letters and exclamation marks. Further emphasis is achieved via exclamations (ouch), fire metaphors (she burned Instagram, the boiling internet) and intensifiers (great, true). All of them start with the woman as a cat metaphor, which is foregrounded and is obviously used to convey an image of a very sexually appealing woman.

Cats are very agile and are of a somewhat independent and wild nature, and these qualities might be associated with sexuality. Additionally, cats are often in heat, with frequent reproduction cycles, and perhaps this too might explain why felines are associated with sexuality. López Rodríguez found the woman as a cat metaphor in both English and Spanish, with more or less the same connotations as those found in our dataset, which could suggest widespread usage of this metaphor in different linguistic and cultural contexts, at least in the Western part of the world. ${ }^{4142}$

Another metaphor with a similar meaning and connotations is that of woman as a fish, which was second-ranked in our dataset according to the number of its instantiations. Unlike the cat metaphor, we have not encountered references to this particular metaphor in the linguistic literature beyond the Balkan region. This might suggest some regional cultural specificity of this particular metaphor although more research would be needed to confirm this thesis. ${ }^{43}$

\footnotetext{
${ }^{41}$ López Rodríguez, p. 84.

${ }^{42}$ A notable example from popular culture based on this stereotype is the movie character of a cat-woman.

${ }^{43}$ We are grateful to an anonymous reviewer of this paper who suggested exploring whether coastline nations have this or similar metaphors, and whether any link to the mermaid mythology could be made. While this is outside the bounds of this work, we hope to see further research in this domain.
} 
Again, we will present a few excerpts containing some linguistic instantiations of this metaphor:

4) „Muškarci su srećni samo ako im je žena dobra riba. Ljepota je muškarcima presudna za uspješan brak, pokazala su najnovija američka istraživanja. Muževi koji pored sebe imaju privlačne supruge imaju duže i srećnije brakove, a što je najvažnije, to zadovoljstvo ne nestaje sa godinama prenosi Cdm." (Kodex.me)

["Men are happy only if their wife is a good fish. Beauty is crucial to a successful marriage for men, according to the latest American research. Husbands who have attractive wives have longer and happier marriages and, most importantly, that satisfaction does not disappear with age, CDM reports."]

5) „Ana Nikolić, koja će se uskoro poroditi, ovako se šali na sopstveni račun! "Svesna sam toga da više nisam dobra riba. U trudnoći se telo promeni, ali mi lice nekako izgleda lepše, kažu da trudnice zrače unutrašnjom lepotom," rekla je ona." (Mondo.me)

["Ana Nikolić, who is about to give birth, is joking like this at her own expense! 'I am aware that I am no longer a good fish. In pregnancy, the body changes, but my face somehow looks more beautiful now, they say that pregnant women radiate inner beauty,' she said."]

Both excerpts 4 and 5 suggest that fish stands for a physically appealing woman, with clear references to beauty and attractiveness in 4 , as well as body, beauty and the attribute beautiful in 5 (in 5, a woman uses a metaphor to address herself as a fish, which is interesting in itself). In our dataset, the noun fish was almost always collocated with the attribute good.

Nataša and Borivoj Gerzić believe that this metaphor is mostly used in the androcentric discourse and that it is produced by two cognitive-linguistic mechanisms: "By metaphorical transmission, the fish becomes a signifier for the female genital organ through the seme of humidity and the fish's mouth (the female genital organ is fish) and then, by metonymy, it becomes the name for the female person (the woman is the female genital organ)". ${ }^{44}$ This suggests a both metaphoric and metonymic mechanism of which the users are unaware. Our data show that fish typically express a good bodily constitution, with some of the examples having overt sexual connotations; however, unlike the cat metaphors which most often had sexual connotations, this was not always explicit in the fish metaphors from our dataset.

We found snakes were used for women quite often in the internet corpus but usually to denote their personality traits, i.e. most often to denote the negative quality of being cunning; however, the metaphor was also used to designate positive physical characteristics - those of a woman having a great body:

6) „ŽENA ZMIJA: Pokazala čuvene OBLINE. Najpoznatija starleta na svijetu, Kim Kardašijan je u kožnom topu i helankama istakla svoje čuvene obline." (www.mondo.me)

["WOMAN SNAKE: She showed her famous CURVES. The most famous starlet in the world, Kim Kardashian, showed off her famous curves in a leather top and leggings.]

${ }^{44}$ Nataša Gerzić and Borivoj Gerzić. Rečnik savremenog beogradskog žargona (Beograd: Istar, 2002). 
7) “'Lilika' pokazala zmijsko tijelo na Zanzibaru!” (www.mondo.me) [“'Lilika' showed her snake body in Zanzibar!" ]

The conceptual metaphor woman is a snake can be used in Montenegrin culture to designate a woman who has a perfectly sculpted body, typically involving appealing curves. In 10 out of 11 instantiations of our dataset, it was found in the phrase "zmijsko tijelo" (snake body). In this metaphor, sexuality is only indirectly conveyed by the fact that a woman has a pleasing body constitution, but no other qualities are explicitly expressed. Therefore, it is used similarly as the cat and fish metaphors, bearing in mind that all three suggest very appealing physical looks. However, we note some slight differences in how they are used - cats typically have sexual connotations; fish are almost invariably found in the phrase "dobra riba" (good fish) and suggest a generally good-looking woman; and snakes are, also almost invariably, used in the phrase "zmijsko tijelo" (trans. snake body), to denote a woman having a good body specifically (not necessarily including the face). Even though these metaphors convey attractiveness, which is seen as a positive quality, the ideology underlying them overstates the importance of a woman's sexual appeal and physical attractiveness and foregrounds these qualities at the expense of the others. She is reduced to these qualities and valued solely based on them in the discourse from our dataset.

In the dataset there were also six realisations of another feline metaphor, woman as a tigress. What follows are two excerpts in which the mentioned metaphor was realised:

8) „Sedam znakova da ste prava tigrica u krevetu!“" (www.kodex.me) ["Seven signs that you are a real tigress $\underline{\text { in bed! !"] }}$

9) „A ako je pripita, može biti prava tigrica u krevetu i opuštenija i razuzdanija nego što bi bila da je trijezna." (www.cdm.me)

["And if she is drunk, she can be a real tigress in bed and more relaxed and debauched than if she were sober."]

The tigress metaphor is used similarly to the cat metaphor to refer to a sexually appealing woman; however, the sexual energy of a woman is additionally emphasised, as evidenced by the fact that it is almost invariably found in the phrase "tigrica u krevetu" (a tigress in bed). A tigress suggests more strength and a wilder nature, as well as an element of danger, in comparison to a cat.

A woman is also compared to a doe in our dataset, to designate a woman who is pretty (10) or gracious and tender (11):

10) „Lepa kao srna.“ (http://nasmej.me/)

["Pretty as a doe."] 
11) „Mlada, kao srna graciozna i nježna; govorila sam joj da je ona moja djevojčica..." (culturecorner.me)

["Young, gracious and tender as a doe; I told her that she was my girl..."]

This animal is also used as a name in Montenegro and the region (Srna) and also vocatively, as a term of endearment ("srno moja", which translates to my doe). This testifies to the existence of a stereotype of this animal standing for a woman who is pretty and/or tender. We did not encounter references to this metaphor in the international linguistic literature. It is definitely used across the region (for instance, there is a reference to it in Balašević's song Život je more). Also, there are references to it in the Bible, for instance, where "the wife of your youth" is compared to a "a loving doe", which certainly points to the direction of the metaphor's universality. ${ }^{45}$

Like tigress, gazelle is another animal not inhabiting the Balkan region; however, this has not stopped the use of the metaphoric expressions containing this animal as the source domain on the Montenegrin webpages. We will quote the excerpts in which it was used below:

12) „Izlazi najzad iz vagona u vidu vitke devojke, vitke kao gazela i preplašene kao mlada srna." (https://makanje.me/)

["She finally gets off the train as a slim girl, slim as a gazelle and frightened as a young doe".]

13) „Nije važno da li nosite potpetice najnajviše ili one malo manje, već da li u njima hodate kao gazela." (https://www.kolektiv.me/)

["It is not important whether you are wearing the highest of heels or those a bit smaller, it is important that you walk as a gazelle in them."]

As evidenced by the excerpts, a gazelle points to a slim woman or a woman having an elegant type of walk, which certainly adds to her attractiveness. Gazelles are rather similar to does, and in 12, in fact, both the metaphors are used together - however, this time a doe designates the quality of being fragile and frightened. Given that gazelles do not live in the Balkans, this metaphor has probably been imported from other languages.

The chicken metaphor is not typical in Montenegro. It was the only bird in the dataset, which is also atypical, as birds have been found to be a frequent source domain when speaking of women in other languages. ${ }^{46}$ In fact, Perović notes that the absence of bird metaphors standing for women in the Balkans could be a cultural specificity of the region. ${ }^{47}$ The one instantiation that was found was used both metaphorically and metonymically:

14) Zanosna Irina Šajk je bila još jedna od manekenki koje su na Kanskom festivalu pokazale "batake".

\footnotetext{
${ }^{45}$ Proverbs 5.18-19.

${ }^{46}$ Zoltan Kövecses, 'Metaphor and Ideology in Slang: The Case of WOMAN and MAN.' Revue d'Études Françaises, 11 (2006), 152-166 (157).

${ }^{47}$ Perović, p. 62.
} 
["The dashing Irina Shayk was one of the models who showed her "chicken drumsticks" at the Cannes Festival. ]

Chicken drumsticks were used under the inverted commas, which points to the fact that this is not a regular expression in Montenegro, which is also confirmed by its low frequency. This was probably a creative use of the metaphor, resting on the idea that chicken legs are typically associated with eating meat and that meat itself is another (degrading) metaphor typically used to denote a good-looking female body. This might also be an allusion to the size and shape of female thighs.

\subsection{Animal metaphors conceptualising unattractive physical appearance}

In this category of metaphors, the source domains included the following animals: mare, duck, giraffe, sow, she-elephant and bear. With the exception of the duck, all of them are rather large animals; therefore, generally, we might frame the general metaphor as an unattractive woman is a big animal.

The conceptual metaphor woman is a mare was the most frequent metaphor used to designate an unattractive woman's physical appearance in the Montenegrin webpages (we found 16 realisations of this metaphor in the dataset). The following realisations illustrate its use:

15) „A onda mi neka kobiletina od 2 m stade štiklom na stopalo." (www.forum.cdm.me) ["And then a $2 \mathrm{~m}$ mare stood on my foot with her heel.]

16) „Kakva KOBILA je ova Tea, ko da su je ubrizgavali hormonima dok je rasla." (www.99tune.me)

["What a MARE this Tea is, as if they were injecting her with hormones as she was growing up."]

Anić notes that a "mare woman" resembles a mare in appearance and also is additionally characterised by vulgar behaviour. ${ }^{48}$ In 15 , the augmentative kobiletina (a huge mare) was used, with the aim of further emphasising the large appearance of such a female person. The woman described by this metaphor is typically very tall and bulky. The accompanying descriptions - $2 m$ in the example 15 and as if they had injected her with hormones in the example 16 - confirm such an interpretation. Thus, we can conclude that the metaphor woman is a mare is used to describe a woman who resembles this animal in her appearance. This quality typically excludes femininity and is pejorative. A woman spoken of in this way is reduced to this negative physical aspect, whereas her other qualities are excluded.

In our dataset, women were also compared to ducks, typically in the expression "duck-face", which is directly transferred from English, either in its original form or the transcription (as

${ }^{48}$ Vladimir Anić, Veliki rječnik hrvatskoga jezika (Zagreb: Novi Liber, 2005). 
dakfejs). The metaphorical expressions with duck also convey an awkward type of walk, resembling that of a duck. The following illustrate both these uses:

17) „Ja mislim da žena treba da izgleda ženstveno, a ne da izgleda kao prostitutka. Ja volim kad je žena lepa, ali nije nužno da imaš grudi i usta i da izgledaš kao patka. I da hodaš kao patka... Većina njih hodaju kao patke, ne znaju da hodaju na štiklama - rekao je Vidić." (www.tracker_ringier_m.contentexchange.me)

["I think that a woman should look feminine, and not like a prostitute. I love when a woman is beautiful, but you don't have to have big boobs and a big mouth and look like a duck. And walk like a duck ... Most of them walk like ducks, they don't know how to walk on high heels - said Vidić."]

18) "Svi su dobro upoznati sa selfijem koji se pravi u "duckface" stilu. Napućene usne, tužan pogled su svi imali, ali izgleda da je i to postalo dosadno." (www.kolektiv.me)

["Everybody is well familiar with the selfie pose made in the 'duckface' style. Pouting lips, a sad look, everybody had it, but it seems that this too has become boring."]

Duck-face is used metonymically, to refer to just one part of a female body; most often this pose is criticised in the corpus, as evidenced in 18, where it is ironically paired with a "sad look" and the obviously critical context in 17 , where women with big lips are said to look like ducks. This type of look suggests awkwardness, either in the appearance itself or the inelegant type of walk resembling that of a duck.

Whereas mares are typically associated with largeness and ducks with an inelegant walk, giraffes usually invoke the picture of an extreme and unappealing height, further made awkward by the disproportionate size of their necks:

18) "Ukoliko ste vrlo visoki... Jedino morate da vodite računa o visini štikle, jer ne želite da izgledate bukvalno kao žirafa." (https://kodex.me/)

["If you are very tall... The only thing you have to take care about is the height of your heels, as you don't want to literally look as a giraffe."]

19) Govorili su da djevojčica lijevo izgleda poput žirafe, a 8 godina kasnije je sve impresionirala svojim izgledom! (https://virealno.me/)

["They used to say that the girl in the left photo looked like a giraffe, but 8 years later she impressed them all by her looks!"]

Unsurprisingly, the giraffe-like look has negative connotations, as evidenced by the examples. Even though this animal does not live in the Balkan region, it is used quite often for comparison to women, owing to its striking physical appearance.

Another conceptual metaphor used in the Montenegrin websites to convey the negative characteristics of women's physical appearance is the metaphor woman is a sow (lexicalised 
as krmača or prasica in the dataset, both of which can be translated as a sow), primarily suggesting obesity in women:

20) „Dženifer Lopez odgovorila na kritike da izgleda kao prasica“" (www.cdm.me)

["Jennifer Lopez replied to criticism that she looked like a sow"]

21) „A onda vidite kako se neka naša pevaljka tokom performansa valja na podu, a izgleda kao krmača pred prasenje." (www.m.cdm.me)

["And then you see our singer rolling on the floor during her performance, and she looks like a sow before giving birth."]

The dominant characteristics of certain animals, their way of life, as well as their attitude, influenced the creation of a collective image of them. Thus, the pig was seen as a dirty, lazy, bulky, sluggish and clumsy animal. These traits are also often associated with immoral behaviour, and females who are large, clumsy, lazy, and untidy, and/or behave indecently, may be conceptualised as sows. The negative image of pigs is a result of their appearance (dirt, neglect, bulkiness), way of walking (slowness, clumsiness, sluggishness), way of life (laziness), their habitat (messy, smelly, dirty), but also the way they eat. Brem et al state that gluttony is the most dominant trait in pigs, in addition to the impurity in which they live. ${ }^{49}$ However, in this paper we focus on the physical properties that sows are associated with and, among them, obesity certainly comes first.

Obesity and largeness are also conveyed by the she-elephant metaphor, but unlike the sow metaphor, other connotations (clumsiness, laziness, untidiness), seem to be missing from its use:

22) „Kada ovo kažu, ljudi uglavnom misle na stomak, ali svejedno; zvuči tako, da se u trenutku osetite kao slonica." (www.wp.me)

["When they say this, people usually think of the stomach, but nevertheless, it sounds so..., you feel like a she-elephant at that moment.]

A woman is also compared to a bear in the corpus - and not a she-bear but to a he-bear, in fact ("međed"). The following is a famous line from a Montenegrin film "The Beauty of Vice" (1986), which is used hundreds of times on the internet but which we decided to count only once in the dataset, as it always appeared in this same sentence form:

23) „S kakvim mi međedom u kući zivot prođe, kukala mi majka.“ (www.m.cdm.me) ["With what a bear I have spent my life at home, poor me."]

The character from the movie refers to his wife via a bear metaphor when he first leaves the village he has spent his whole life in and comes to the seaside, where he sees half-naked women on the beach. The line is used ironically as a comic relief in the film but is, unfortunately, very often quoted in the region, for humorous effect, by married men criticising

${ }^{49}$ Alfred Edmund Brem, Kako žive životinje (Rijeka: Otokar Keršovani, 1967). 
the looks of their wives. This metaphor could also be subsumed under what Perović puts as woman is a male animal, with an additional disparaging effect, as a woman thus referred to is completely devoid of femininity, being large and probably hairy. ${ }^{50}$ Even though this metaphor was used creatively in the film, we may now say that it has become rather established in Montenegro.

\section{Conclusions}

In this paper we analysed the animal metaphors used to conceptualise women's physical appearance in the Montenegrin culture based on a corpus of Montenegrin webpages, from which we had extracted a dataset of 106 excerpts. There were two general types of these metaphors - those expressing attractive and those expressing unattractive physical properties of women, with a stark polarisation between the two and no neutral metaphors. The cultural views underlying the metaphors overstate the importance of a woman's sexual appeal and her physical attractiveness, as well as foreground these qualities at the expense of the others. Moreover, the fact that no neutral metaphors were found further confirms how critical physical appearance is for a woman in Montenegro. Additionally, many of the metaphors were used with sexual connotations, which reveals how rooted sexism is in Montenegrin culture. Our findings thus corroborate those by Perović ${ }^{51}$ and Bratić and Vuković-Stamatović. ${ }^{52}$

In the category of metaphors conveying what the internet users saw as attractive physical qualities, the source domains included the following animals: cat, fish, tigress, doe, gazelle, chicken and snake. We found that attractive physical looks were typically associated with small-sized wild animals. Most of these metaphors may be said to be universal, except for the fish metaphor which might be a cultural specificity of the region, although we said that more cross-cultural research would be needed to confirm this thesis. The cat, fish and snake metaphors conveyed similar attractive physical qualities, with some slight differences - cats typically had sexual connotations; fish suggested a generally good-looking woman, whereas snakes denoted a woman having a good body specifically. While the cat metaphors were used more creatively, the fish and snake metaphors were found almost invariably in certain fixed phrases. The tigress metaphor was used similarly to the cat metaphor, but the sexual energy of a woman was additionally emphasised - a common sexual thread in these feline metaphors was obvious. Doe and gazelle, on the other hand, were also similarly used, to denote a slim attractive woman, typically having an elegant walk. Additionally, there were virtually no bird metaphors in the corpus - our research thus confirmed Perović's thesis that the absence of bird metaphors standing for women in the Balkans could be a cultural specificity of the region. ${ }^{53}$

The animal metaphors used with the aim of conveying negative characteristics concerning the physical appearance of a woman were the following: mare, duck, giraffe, sow, she-elephant and

\footnotetext{
50 Perović, p. 59.

51 Perović, pp. 58-62.

52 Bratić and Vuković-Stamatović, pp. 51-76.

${ }^{53}$ Perović, p. 62.
} 
bear. With the exception of the duck, all of them were rather big animals, which is why the general metaphor an unattractive woman is a big animal was typical of the corpus. Therefore, based on the research conducted, we can conclude that in Montenegrin culture, the names of large animals are used to convey negative characteristics related to a woman's physical appearance, while the names of smaller animals are generally used to describe attractive women. This is parallel to what López Rodríguez found for English and Spanish, which points to some universality in the metaphorical analogy applied. ${ }^{54}$ Some of the metaphors from this category were definitely international (e.g. duck), whereas some could be culturally more specific (e.g. bear). The latter was originally coined in a film but has been established over time in Montenegro, showing how language can contribute to entrenching negative stereotypes about women.

Furthermore, the analysis of the dataset points in the direction that, in Montenegrin culture, the names of domestic animals are typically used to convey unattractive female physical appearance (with the exception of cat), while the names of wild animals are mainly used to convey positive values (with the exception of large wild animals). Thus, we can conclude that man is more inclined to attribute negative traits to animals that he has tamed and subjugated, than to wild animals over which he has no control, which pose a threat to him, which he fears and also admires.

We hope that with this study we have contributed to the research on how women are conceptualised across languages and cultures. A further research step could be to study the data from the other regional domains (.hr, .rs and .ba), i.e. to encompass the results from Croatia, Serbia and Bosnia and Herzegovina - a larger dataset would add to the validity of the results and more in-depth interpretations. Diachronic analyses could also be possible currently, the .me domain, which has been in use for just over a decade by the relatively small Montenegrin population, does not yield sufficient data of the type needed for this study. Finally, further research could certainly go in the direction of contrasting such conceptualisations to how men are conceptualised, as well as how women are conceptualised in some other languages, which could allow for a cross-comparison of the results.

54 López Rodríguez, pp. 94-96. 


\section{Bibliography}

Anić, Vladimir, Veliki rječnik hrvatskoga jezika (Zagreb: Novi Liber, 2005).

Badurina, Lada, Ivo Pranjković and Josip Silić (eds.), Jezični varijeteti i nacionalni identiteti Zagreb: Disput, 2009).

Bratić, Vesna and Milica Vuković-Stamatović, 'Commodification of women through conceptual metaphors: The metaphor woman as a car in the Western Balkans.' Gender and Language, 10.3 (2017), 51-76.

Brem, Alfred Edmund, Kako žive životinje (Rijeka: Otokar Keršovani, 1967).

Bugarski, Ranko. Jezik i identitet (Beograd: Biblioteka XX vek, 2010).

Charteris-Black, Jonathan, Corpus Approaches to Critical Metaphor Analysis (New York: Palgrave Macmillan, 2004).

George, Lakoff, and Mark Johnson. Metaphors We Live by (Chicago and London: The University of Chicago Press, 1980).

Gerzić, Nataša and Borivoj Gerzić. Rečnik savremenog beogradskog žargona (Beograd: Istar, 2002).

Glušica, Rajka, 'Crnogorski jezik u čeljustima nacionalizma.' Riječ, 4 (2010), 25-45.

Granić, Jagoda, 'Planiranje statusa i planiranje korpusa bosanskog/bošnjačkog, hrvatskog i srpskog standarda', in Die Unterschiede zwischen dem Bosnischen/Bosniakischen, Kroatischen und Serbischen, ed. by Branko Tošović and Arno Wonisch (Graz-Zagreb: Institut für Slawistik der Karl-Franzens-Universität Graz, 2008), pp. 17-33.

Halupka-Rešetar, Sabina and Biljana Radić. 'Animal Names Used in Addressing People in Serbian.' Journal of Pragmatics, 3 (2003), 1891-1902.

Hines, Caitlin, 'Foxy chicks and playboy bunnies: A case study in metaphorical lexicalisation.' Amsterdam Studies in the Theory and History of Linguistic Science Series, 4 (1999), 9-24.

Hines, Caitlin, 'Rebaking the pie: the woman as dessert metaphor,' in Reinventing Identities: The Gendered Self in Discourse, ed. by Mart Bucholtz, Anita C. Liang, and Laurel A. Sutton (Oxford: Oxford University Press, 1999), pp. 145-162.

Kilyeni, Annamaria and Nadežda Silaški. 'Beauty and the beast from a cognitive linguistic perspective: Animal metaphors for women in Serbian and Romanian.' Gender Studies, 13.1 (2014), 163-178. 
Klikovac, Duška, Metafore u mišljenju i jeziku (Beograd: Biblioteka XX vek, 2004).

Kordić, Snježana, 'Policentrični standardni jezik' in Jezični varijeteti i nacionalni identiteti, ed. by Lada Badurina, Ivo Pranjković and Josip Silić (Zagreb: Disput, 2009): pp. 83-108.

Kövecses, Zoltan, 'Metaphor and Ideology in Slang: The Case of WOMAN and MAN.' Revue d'Études Françaises, 11 (2006), 152-166.

_-, Metaphor: A practical introduction (Oxford: Oxford University Press, 2010).

Lakoff, Robin, 'Language and woman's place.' Language in Society, 2.1 (1973), 45-79.

López Rodriguez, Irene, 'Of women, bitches, chickens and vixens: animal metaphors for women in English and Spanish.' Cultura, Lenguaje y Representación/Culture, Language and Representation, 7.7 (2009), 77-100.

Margaret Nasambu, Barasa and Isaac Nilson Opande. 'The use of animal metaphors in the representation of women in Bukusu and Gusii proverbs in Kenya.' Africology: The Journal of Pan African Studies, 10.2 (2017), 82-108.

Mills, Sarah, Language and Sexism (Cambridge: Cambridge University Press, 2008).

Muratagić-Tuna, Hasnija, Bosanski, hrvatski, srpski aktuelni pravopisi: sličnosti i razlike (Sarajevo : Bosansko filološko društvo, 2005).

Musolff, Andreas, Metaphor And Political Discourse: Analogical Reasoning in Debates about Europe (Basingstoke: Palgrave Macmillan, 2004).

- -, 'Dehumanising metaphors in UK immigrant debates in press and online media.' Journal of Language Aggression and Conflict, 3, 1 (2015), 41-56.

--, Political Metaphor Analysis: Discourse and Scenarios (London: Bloomsbury Publishing, 2016).

Perović, Slavica, Pojmovna metafora kulturno srodnih pojmova (Podgorica: Crnogorska Akademija Nauka i Umjetnosti, 2017).

Perović, Slavica and Milica Vuković-Stamatović, 'Universality and cultural variation in the conceptualisation of love via metaphors, metonymies and cultural scripts: the case of Montenegrin.' Círculo de Lingüistica Aplicada a la Comunicación, 85 (2021), 45-61.

Pragglejaz Group, 'MIP: A Method for Identifying Metaphorically Used Words in Discourse.' Metaphor and Symbol, 22.1 (2007), 1-39. 
Semino, Elena and Michela Masci, 'Politics is football: metaphor in the discourse of Silvio Berlusconi in Italy.' Discourse \& Society, 7.2 (1996), 243-269.

Semino, Elena, Metaphor in Discourse (Cambridge: Cambridge University Press, 2008).

Silaški, Nadežda, 'Animal Metaphors and Semantic Derogation-Do Women Think Differently from men?' Gender Studies, 12 (2013), 319-332.

Steen, Gerard, 'Towards a procedure for metaphor identification.' Language and Literature, 11.1 (2002), 17-33.

Stefanowitsch, Anatol and Stefan Gries, Corpus-Based Approaches to Metaphor and Metonymy (Berlin: Mouton de Gruyter, 2006).

Tepavčević, Ivan, 'Jedan pogled na položaj žena u crnoj gori u XIX i početkom XX vijeka.' Folia Linguistica et Litteraria, 21 (2018), 237-247.

Tipler, Caroline and Janet Ruscher, 'Dehumanizing representations of women: The shaping of hostile sexist attitudes through animalistic metaphors.' Journal of Gender Studies, 28.1 (2019), 109-118.

Vujković, Violeta, 'The conceptual metaphor woman is an animal in Montenegrin webpages.' Logos et Littera, 6.1 (2019), 67-80.

- - Konceptualizacija žene putem animalnih metafora u korpusu britanskih i crnogorskih internet stranica (unpublished master's thesis, University of Montenegro, 2020).

Zinken, Jörg, lina Hellsten and Brigitte Nerlich, 'Discourse metaphors.' Body, Language and Mind, 2 (2008), 363-385. 